\title{
Trophic ecology of the seagrass-inhabiting footballer demoiselle Chrysiptera annulata (Peters, 1855); comparison with three other reef-associated damselfishes
}

\author{
Gilles Lepoint 1,", Loïc N. Michel ${ }^{1}$, Eric Parmentier ${ }^{2}$ \& Bruno Frédérich ${ }^{2}$
}

\author{
1 Laboratory of Oceanology, MARE Centre, University of Liège \\ 2 Laboratory of Functional and Evolutionary Morphology, AFFISH Research Centre, University of Liège \\ * Corresponding author: G.Lepoint@ulg.ac.be
}

\begin{abstract}
Many damselfishes (Pomacentridae) are herbivorous or omnivorous with an important contribution from different kinds of algae in their diet. They display different levels of territoriality and farming behavior, from almost non territorial to monoculture farmers. In addition, a few species inhabit seagrass meadows but, presently, none can be considered as seagrass-eating specialists. The footballer demoiselle, Chrysiptera annulata, is found in the seagrass meadows on the reef flat of the Great Reef of Toliara (Madagascar, Mozambique Channel). In the light of this unusual habitat for a pomacentrid, this study aimed to answer three questions: 1) What is the diet of $C$. annulata? 2) Do the resources supporting this diet include seagrass? 3) Does its trophic niche overlap those of other sympatric damselfishes (Pomacentrus trilineatus, Chrysiptera unimaculata and Plectroglyphidodon lacrymatus) living in close association with macrophytes or eating algae? Stomach content examination and stable isotope analysis showed that the footballer demoiselle is not a seagrass consumer but is an omnivorous/herbivorous species heavily relying on algal resources and small invertebrates. SIAR, a stable isotope mixing model, indicated it assimilated large amounts of turf algae, and various benthic or planktonic invertebrates in lower proportions. SIBER metrics revealed that the isotopic niche of the footballer demoiselle partly overlaps that of its congener, $C$. unimaculata, but not those of $P$. trilineatus and $P$. lacrymatus. Trophic strategies of $C$. annulata differed both from farming species such as P. lacrymatus and from less territorial herbivores such as $P$. trilineatus. Its seagrass meadow habitat on the Great Reef of Toliara allows the conquest of an unusual habitat for damselfishes and could limit competition with C. unimaculata, a species displaying the same territorial behavior and the same isotopic niche but living on the reef itself.
\end{abstract}

KEY WORDS: herbivory, stable isotopes, coral reef, seagrass, trophic niches, Western Indian Ocean, SIAR, SIBER.

\section{INTRODUCTION}

The Great Reef of Toliara (SW Madagascar, Mozambique Channel) was once one of the most diverse coral reefs in the Western Indian Ocean (WIO) (PICHON, 1978). Unfortunately, recent observations highlight drastic changes in its biodiversity (HARRIS et al., 2008; ANDRÉFOUËT et al., 2013). Coral cover has drastically decreased on the reef flat with the disappearance of branched Acropora spp. (HARRIS et al., 2008) whereas macroalgae cover has significantly increased between 1978 (PICHON, 1978) and 2008 (HARRIS et al., 2008). Concomitantly, fish communities have also changed as they were previously dominated by carnivores (HARMELINVIVIEN, 1979) and are now dominated by herbivores and omnivores (HARRIS et al., 2008).

Since large herbivore biomass is strongly affected by overfishing on the Great Reef of Toliara, most of the remaining herbivores are small species such as damselfishes (Pomacentridae) (HARRIS et al., 2008; FRÉDÉRICH, pers. obs). Herbivorous fishes display a high trophic diversity due to differences in ingested species, nutritional strategies, eco-morphological adaptations, contribution from other food sources or foraging patterns (CHOAT et al., 2004; FOX \& BellWoOD, 2013; BellwoOd et al., 2014). 
For example, some species may be classified as "roving herbivores" (or foragers), sometimes forming schools, having no feeding territories (or very large territories) and/or exploiting diverse habitats for feeding (FRÉDÉRICH et al., 2009; GULLSTRÖM et al., 2011; PLASS-JOHNSON et al., 2013). Others may be solitary, territorial and restricted to a particular area for feeding (FISHELSON, 1998; CECCARELLI et al., 2005). An extraordinary adaptation of some damselfishes is to garden these small territories, determining the algal community and abundance within the small area they defend against conspecifics and other herbivores (CECCARELLI et al., 2005). The occurrence of multiple herbivorous damselfish species raises the question of the diversification and overlap of trophic niches among these species.

The footballer demoiselle, Chrysiptera annulata (PETERS, 1855), is one of the smallest pomacentrids (FISHELSON, 1998). It is a Western Indian Ocean (WIO) species, inhabiting reef flats of the southern Malagasy coast (GILLIBRAND et al.,2007) but also other islands of the Mozambique Channel (WICKEL et al., 2014) as well as the East African coast (GARPE \& ÖHMAN, 2003) and the Red Sea (KHAlAF, 2004). Chrysiptera annulata is a solitary species, defending, against conspecifics, small areas $\left(<1 \mathrm{~m}^{2}\right)$ constituted by a small coral boulder often bearing macroalgae such as Padina spp., Sargassum spp or Turbinaria spp. (FISHELSON, 1998). On the Great Reef of Toliara, C. annulata is almost restricted to subtidal seagrass meadows found on the reef flat. This particular habitat and territorial behaviour raise the question about the contribution of plant materials to its diet and about its potential consumption of seagrass. Seagrass consumption and/or assimilation by animals were traditionally considered as negligible to very low due to their low palatability (CEBRIAN, 2002). Nevertheless, seagrass herbivory is highly variable and its level differs in tropical and in temperate and high latitude seagrass meadows (HECK \& VALENTINE, 2006). Indeed, tropical seagrass palatability is probably comparable to many macroalgae (KLUMPP et al., 1993) and more consumers than assumed before seem to depend on seagrasses for their food (VONK et al., 2008). Among reef fishes, seagrass consumption is unambiguous for some scarid species (GULLSTRÖM et al., 2011) but it is not demonstrated for pomacentrids living in seagrass beds (e.g. NAKAMURA et al., 2003).

Stable isotopes have a long history as a powerful method allowing the assessment of trophic ecology of fishes and other animals (LAYMAN et al., 2012). The method relies upon the fact that the isotopic composition of a consumer is the weighted average of the isotopic compositions of its food sources, modified by the net isotopic fractionation between diet and animal tissues (i.e. the change of the isotopic composition of food sources during food processing, assimilation and metabolism). A more recent application of stable isotopes analysis is to characterize the trophic niche using the isotopic variability inside communities, species or populations (LAYMAN et al., 2007; NEWSOME et al., 2007). This so-called "isotopic niche" is generally used as a proxy of the trophic niche.

Here, we used measurements of carbon and nitrogen isotopic ratios and stomach content analysis to investigate trophic ecology of $C$. annulata in the seagrass meadows from the Great Reef of Toliara. Our first objective was to determine whether this damselfish was herbivorous and whether the consumption of seagrass could represent an unexpected specialization of this species. Our second goal was to test the hypothesis that different herbivorous damselfishes may have different isotopic niches in relation to differences in their habitat, feeding strategy or behaviour. We have therefore compared the isotopic niche of the footballer demoiselle to those of three other damselfishes from the Toliara great reef: (1) Pomacentrus trilineatus Cuvier 1830, an omnivorous species with significant contribution from algae in its diet (FRÉDÉRICH et al., 2009), often living in small aggregations on the coral reef flat and considered as a less territorial species (gregarious polydomous sensu FISHELSON, 1998); (2) Chrysiptera unimaculata (CUVIER, 1830), an algivorous species also living on the coral reef flat (FRÉDÉRICH et al., 2009) and being 
territorial but not considered as a strict farmer in this location (FRÉDÉRICH, personal observation); and (3) Plectroglyphidodon lacrymatus (QUOY \& GAYMARD, 1825), a well-known territorial farming species (JONES et al., 2006) living in the lagoon (FRÉDÉRICH et al., 2009).

\section{MATERIALS AND METHODS}

Chrysiptera annulata $(\mathrm{n}=35)$ were sampled by scuba diving in May 2011 on the flat of the Great Reef of Toliara (6 $\mathrm{m}$ depth at high tide, less than $3 \mathrm{~m}$ at low tide). Thirty individuals were sampled in monospecific Halophila stipulacea seagrass patches or Syringodium isoetifoliumdominated polyspecific patches (secondary species: Cymodocea rotundata and Halodule uninervis). Five were collected close to this area in a site with coral boulders colonized by brown algae (Sargassum spp.) but without seagrass meadows. Fish were always closely associated to little rocks or coral rubbles (territories less than $1 \mathrm{~m}^{2}$ and almost equal between individual) bearing sometimes large erect brown macroalgae (Sargassum spp. or Turbinaria sp. for example), foliose macroalgae (e.g. Padina spp.) and smaller erect (Hypnea spp.) and always turf macroalgae (Polysiphonia spp.), growing on the boulder or as epiphytes of large erect algae. Each territory was defended by one individual and occupied by 1 to 4 individuals. All C. annulata specimens were collected between 9:00 and 12:00 am after being anesthetized with clove oil. Twenty-nine specimens of Pomacentrus trilineatus were also collected from two sites distant a few hundred metres and close to the area where we caught $C$. annulata specimens. Specimens of Pomacentrus trilineatus were caught along the slope of small water basins locally called "vasques", which constitute deeper water areas within the reef flat and are colonized by living corals but were devoid of seagrass patches.

After their capture, fishes were brought to the surface, killed by immersion in MS-222 and placed on ice before return to the laboratory. In the laboratory, standard length (SL) was measured to the nearest $\mathrm{mm}$ with a Vernier calliper and fishes were dissected to collect samples (approx. $2 \mathrm{~cm}^{3}$ ) of lateral muscle tissue for stable isotope analysis. The entire digestive tract was then removed and conserved in $70 \%$ ethanol for stomach content analysis.

For each individual, potential food sources (i.e. seagrass, erect macroalgae, their respective epiphytes and other macroalgae attached to rocks and rubbles) were also sampled for isotopic analysis. Potential animal food sources such as zooplankton and small benthic invertebrates (e.g., isopods and harpacticoid copepods) were taken from the fish collection site according to the methodology described in FRÉDÉRICH et al. (2009). Suspended particulate organic matter was collected by filtering five litres per sample of pre-sieved $(250 \mu \mathrm{m})$ seawater from the collection site on a glass fibre filter (GF/C, Whatman).

\section{Stomach content analysis}

Stomachs were opened and their contents visually examined using a Wild M10 binocular microscope. First, the methodology of WILSON \& BELLWOOD (1997) was used in order to quantify food items. Stomach contents were spread over a Petri dish, covering a $15 \times 15$ square grid $(5 \times 5 \mathrm{~mm})$ placed underneath. For each of 50 randomly marked grid quadrats, the dominant item (by area) was recorded, along with any other material present in the quadrat. The data were condensed into seven categories: turf algae, erect macroalgae, seagrass, sessile benthic invertebrates, vagile benthic invertebrates, zooplankton and undetermined (i.e. item impossible to identify). Then, we calculated the contribution of each category within stomach content, and values for each category were expressed as the percent of quadrats in which that category was dominant. Finally, we also calculated the percentage of occurrence of each of the seven food categories (HYSLOP, 1980).

\section{Stable isotope analysis}

Samples of lateral muscle tissue from $C$. annulata and $P$. trilineatus and potential 
food sources were dehydrated for $24 \mathrm{~h}$ at $50^{\circ} \mathrm{C}$ before being ground into an homogenous powder. After grinding, samples containing carbonates (calcified algae, zoobenthos and zooplankton) were placed for $24 \mathrm{~h}$ under a glass bell with fuming $\mathrm{HCl}$ (37\%) (Merck, for analysis quality) in order to eliminate calcareous material. Carbon and nitrogen stable isotope ratios of fishes were analysed on an IR-MS (Isotope Ratio Mass Spectrometer, VG Optima, Micromass, UK) coupled to an N-C-S elemental analyser (NA1500, Carlo Erba, Italy). Isotopic ratios of food sources were measured on IRMS (Isoprime 100, Isoprime, UK) coupled with N-C-S elemental analyser (Vario Microcube, Elementar, Germany). Stable isotope ratios were expressed in $\delta$ notation according to COPLEN (2011). Certified materials were IAEA-N1 $\left(\delta^{15} \mathrm{~N}=+0.4 \pm 0.2 \%\right.$ ) and IAEA CH-6 (sucrose) $\left(\delta^{13} \mathrm{C}=-10.4 \pm 0.2 \%\right)$. Routine measurements were precise to within $0.3 \%$ for both $\delta^{13} \mathrm{C}$ and $\delta^{15} \mathrm{~N}$.

\section{Data treatment and statistics}

The stable isotope mixing model SIAR (Stable Isotope Analysis in R) was used to estimate the relative contribution of different prey species (isotopic sources) to the diet of footballer demoiselle (PARNELL et al., 2010). SIAR (Version 4.2) was fitted in $\mathrm{R}$ ( $\mathrm{R}$ 3.1.3, $\mathrm{R}$ Development Core Team 2008) including isotopic compositions of each consumer, isotopic compositions of food sources and trophic enrichment factors (TEFs; expressed as mean $\pm \mathrm{SD}$ ) that correspond to the net isotopic composition change between a consumer and its ingested food source(s). Model was run with the following potential food sources: zooplankton, zoobenthos and turf algae. For carbon, we have used a unique TEF factor of $1.6 \pm 0.5 \%$ which was already used by DROMARD et al. (2015) and is in the range of generally observed TEF for ${ }^{13} \mathrm{C}$ in omnivorous fishes (PLASS-JOHNSON et al., 2013). TEFs for nitrogen were adapted according to food type potentially assimilated by the fish. For algal sources, we have used a TEF of $5.1 \pm 0.6 \%$ (adapted from MiLL et al., 2007), which is observed for farmer damselfishes such as Stegastes spp. (HATA \& UMEZAWA, 2011) or herbivorous scarids and acanthurids (MILL et al., 2007). For animal sources, we have used a TEF for nitrogen of $2.3 \pm 0.5 \%$, calculated by DROMARD et al. (2013) using equations of CAUT et al. (2010). Model was run with $10^{6}$ iterations and burn-in size was set as $10^{5}$. Model solutions were presented using credibility intervals of probability density function distributions (PARNELl et al., 2010).

Isotopic niche parameters were computed using SIBER (Stable Isotope Bayesian Ellipses in R; JACKSON et al., 2011), a part of the R package SIAR (see above). Isotopic data used for C. unimaculata and Pl. lacrymatus come from FRÉDÉRICH et al. (2009). They were measured on fish taken close to the present study location (less than $500 \mathrm{~m}$ ) in 2008, measured in the same laboratory using continuous flow EA-IRMS. SIBER was used to generate bivariate standard ellipses that represent core isotopic niches of consumers. Areas of the ellipses associated to each species $\left(\mathrm{SEA}_{\mathrm{B}}\right)$ were computed using Bayesian modelling ( $10^{6}$ iterations), and direct pairwise comparisons of SEA S $_{B}$ were performed. Model solutions were presented using credibility intervals of probability density function distributions.

Relationship between stomach contents and fish size were tested through linear regressions. Differences among stable isotopic compositions of food sources and consumers were tested using a non-parametric Kruskal-Wallis test, because conditions for parametric approach were not respected for all groups. Dunn's Multiple Comparison Tests were used to assess pairwise differences when Kruskal-Wallis revealed statistically significant effects. A Mann-Whitney $\mathrm{U}$ test was used to test difference between the stable isotopes composition of $P$. trilineatus in their two sampling locations. All test results were considered as significant when $\mathrm{p}$ was $\leq 0.05$. Statistical analyses were conducted using Prism 5.04 (GraphPad Software, La Jolla, U.S.A.). 


\section{RESULTS}

\section{Stomach contents of Chrysiptera annulata}

Stomach contents are composed of diverse fractions but are dominated by filamentous turf algae (Table 1, Fig. 1). 97\% of fish showed turf algae in their stomach content (Table 1) and this item accounted for more than $55 \%$ of the stomach content in the great majority of studied specimens (Fig. 1). The relative amount of turf algae was the only item that was positively correlated to fish size $\left(R^{2}=0.20 ; p=0.01\right.$; Fig. 1$)$. Seagrass fragments were observed in the stomach of only two specimens ( $6 \%$ frequency of occurrence), despite the fact that 30 individuals out of 35 were caught on small territories at the border of or within seagrass patches (Table 1). The amount of erect macroalgae found in stomach contents was generally negligible. Zooplankton contributed importantly to the diet of smaller specimens. This contribution tended to decrease as size increased and was equal to zero from a size of $50 \mathrm{~mm} \mathrm{SL}$
(Fig. 1) $\left(\mathrm{R}^{2}=0.20 ; \mathrm{p}<0.01\right)$. Vagile benthic fauna was found in $36 \%$ of individuals and was mainly present in individuals from 25 to $50 \mathrm{~mm} \mathrm{SL}$ (Fig. 1). However its average contribution to the stomach content was lower than zooplankton. Undetermined items were found in $96 \%$ of individuals, and may represent a non-negligible part of stomach contents (Table 1).

\section{Stable isotopes composition of food sources and their potential consumers}

No significant difference was found in $\delta^{15} \mathrm{~N}$ values of potential food sources (KruskalWallis test, $\mathrm{p}>0.05$ ) (Fig. 2). On the other hand, food sources varied significantly in their $\delta^{13} \mathrm{C}$ values (Kruskal-Wallis test, $\mathrm{p}<0.05$ ). There were significant differences between $\delta^{13} \mathrm{C}$ values of Sargassum spp. and of the two dominant seagrasses $H$. stipulacea and $S$. isoetifolium (Dunn's Multiple Comparison Test, $\mathrm{p}<0.05$; Fig. 2). $\delta^{13} \mathrm{C}$ values of seagrasses differed significantly from those of zooplankton

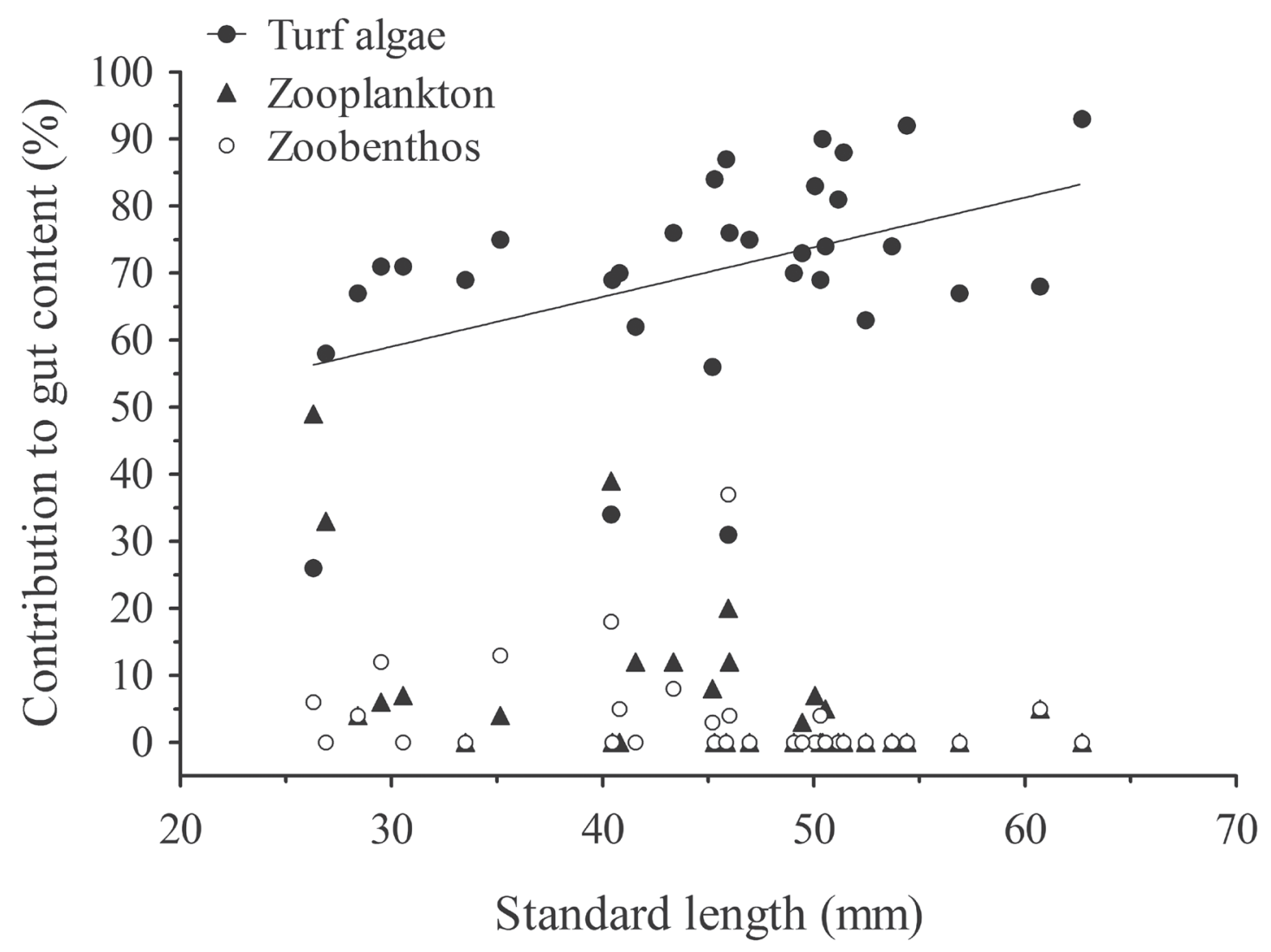

Fig. 1. - Contribution from three food categories (\%) vs standard length ( $\mathrm{mm})$ of the footballer demoiselle, Chrysiptera annulata $(\mathrm{n}=33)$. 
TABLE 1

Stomach content analysis (\%) and occurrence frequency (\%) in stomachs of Chrysiptera annulata $(\mathrm{n}=35)$.

\begin{tabular}{lcccccc}
\hline & Turf algae & Zooplankton & Zoobenthos & Seagrass & Fish scales & Undetermined \\
\hline Mean $( \pm \mathrm{SD})$ & $70.1 \pm 16$ & $7.1 \pm 12.1$ & $3.6 \pm 7.5$ & $0.1 \pm 0.6$ & $0.8 \pm 2.4$ & $18.2 \pm 9.6$ \\
Minimum & 25.7 & 0.0 & 0.0 & 0.0 & 0.0 & 0.0 \\
Maximum & 93.3 & 48.6 & 37.1 & 25 & 11.1 & 33.3 \\
Occurrence frequency & 97 & 48 & 36 & 6 & 12 & 94 \\
\hline
\end{tabular}

(Dunn's Multiple Comparison Test, $\mathrm{p}<0.05$ ) but not from those of zoobenthos. Zoobenthos $\delta^{13} \mathrm{C}$ values differed significantly from those of Sargassum spp. (Dunn's Multiple Comparison Test, $p<0.05) . \quad \delta^{13} \mathrm{C}$ values of associated organisms (i.e. seagrass epiphytes, Sargassum epiphytes or macroalgae growing within the territories) did not differ from each other or from their host plant, except Padina sp. whose $\delta^{13} \mathrm{C}$ values differed significantly from those of Sargassum spp. and zooplankton (Dunn's Multiple Comparison Test, $\mathrm{p}<0.01)$.

$\delta^{13} \mathrm{C}$ and $\delta^{15} \mathrm{~N}$ values of $C$. annulata varied between -13.9 and $-16.2 \%$ (mean \pm S.D., -15.1 $\pm 0.6 \%$ ) and between 7.8 and $8.8 \%$ (mean \pm S.D., $8.2 \pm 0.2 \%$ ), respectively (Fig. 2). SIAR modelling output (Fig. 3) indicated that zoobenthos contributed the least in the diet of C. annulata (mean: 22\%, 95\% credibility interval 15-29\%). Algae contribution to the diet was the more variable (mean: 35\%, 95\% credibility interval 23-48\%) and zooplankton, upon average, represented the most important food sources in the C. annulata diet (mean: $43 \%$, 95\% credibility interval: $35-50 \%$ ).

$\delta^{15} \mathrm{~N}$ values of $P$. trilineatus varied significantly between the two sampling locations (MannWhitney U test, $\mathrm{p}<0.05$; Fig. 2).

\section{Isotopic niche parameters}

There was relatively little overlap among the isotopic niches of the four damselfish species

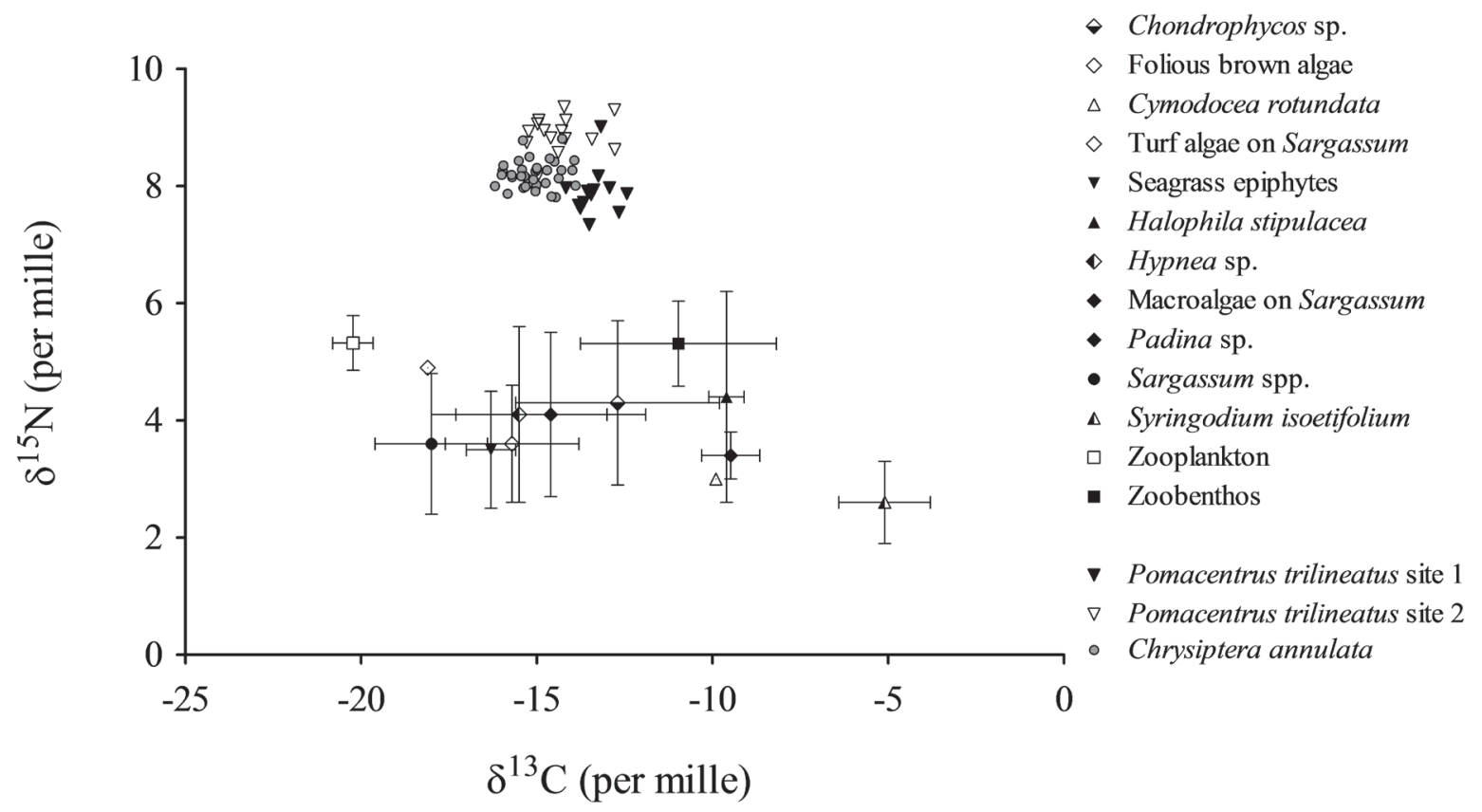

Fig. 2. $-\delta^{13} \mathrm{C}$ vs $\delta^{15} \mathrm{~N}$ of potential food sources (mean $\pm \mathrm{sd}$ ), Chrysiptera annulata and the two populations of Pomacentrus trilineatus (individual data points, $\mathrm{n}=35$ and $\mathrm{n}=29$, respectively). 
(Fig. 4a). There was no overlap at all between the two groups of $P$. trilineatus or between $P l$. lacrymatus and the four other groups. The highest overlap was between $C$. annulata and C. unimaculata $\left(0.171 \%^{2}\right.$, i.e. about $40 \%$ of the isotopic niches of both species). Standard ellipse area $\left(\mathrm{SEA}_{\mathrm{b}}\right)$ of $C$. annulata was similar to the one of C. unimaculata, Pl. lacrymatus and the $P$. trilineatus of location 1 , but was smaller than the one of the $P$. trilineatus of sampling location 2 in $97.44 \%$ of model estimates (Fig. 4b).

\section{DISCUSSION}

Analyses of stomach contents and stable isotopes demonstrate that $C$. annulata is an omnivorous/herbivorous species heavily relying on algal resources on the Great Reef of Toliara. Our findings on the animal contributions to stomach contents are in agreement with previous studies (HARMELIN-VIVIEN, 1979; ALLEN \& RANDALL, 1980) but show also that turf algae are the dominant food item ingested by all individuals, except by the smallest ones. This is not astonishing since turf algae are often dominant in the stomach contents of omnivourous/herbivorous damselfishes (JONES et al., 2006; FRÉDÉRICH et al., 2009; DROMARD et al., 2013). On the other hand, stable isotopes and SIAR modelling suggested that planktonic, and to a lesser extent, benthic animals were also important contributors to the diet of the footballer demoiselle. Three non-exclusive hypotheses can explain these apparent discrepancies. Firstly, stomach contents indicated that small individuals ingest more animal preys than do larger ones, and that turf algae progressively dominated the diet during growth. Measured isotopic compositions in fish muscle represent integration from the fish diet probably over a period of 1-2 months, as opposed to stomach contents, which are snapshots of the diet (e.g. CAUT et al., 2010). Therefore, even for large individuals, stable isotope composition could reflect the contribution of animal consumption from past month(s). Secondly, stable isotopes

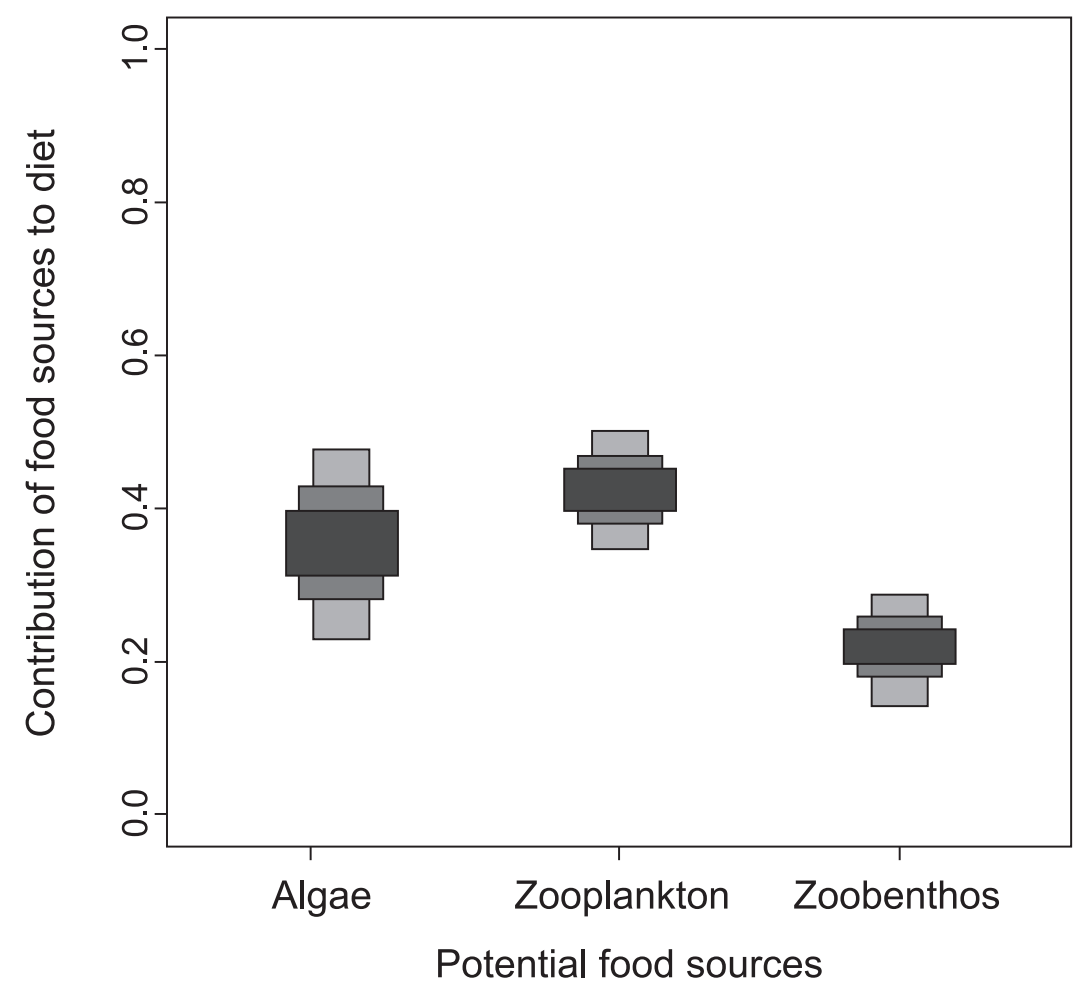

Fig. 3. - Boxplots showing relative contributions of potential food items to Chrisyptera annulata diet, computed using the SIAR model. Dark, median and light grey boxes are respectively the $50 \%, 75 \%$ and $95 \%$ credibility intervals of the probability of density function distributions of the model solutions 
$4 \mathrm{~A}$

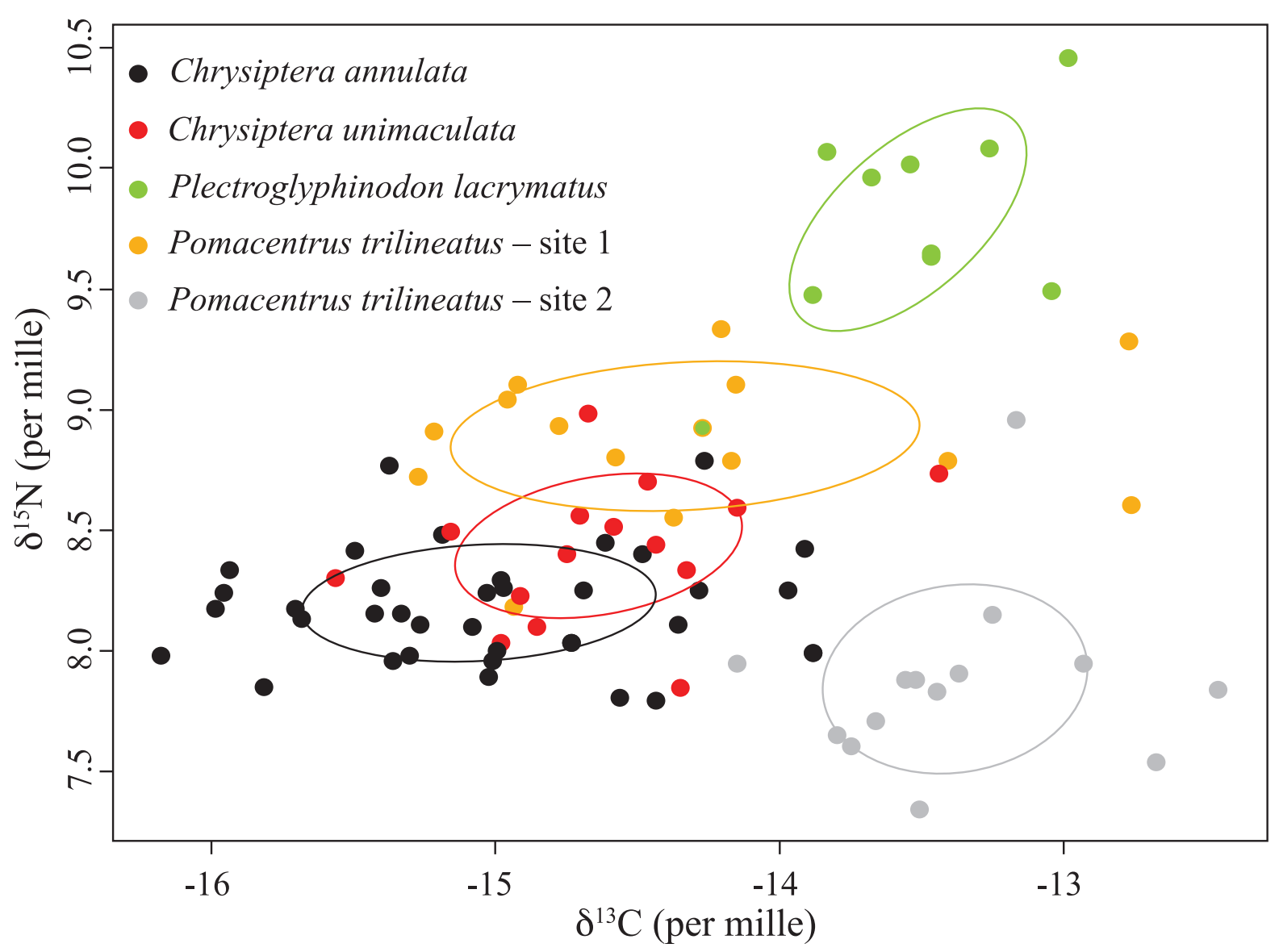

4B

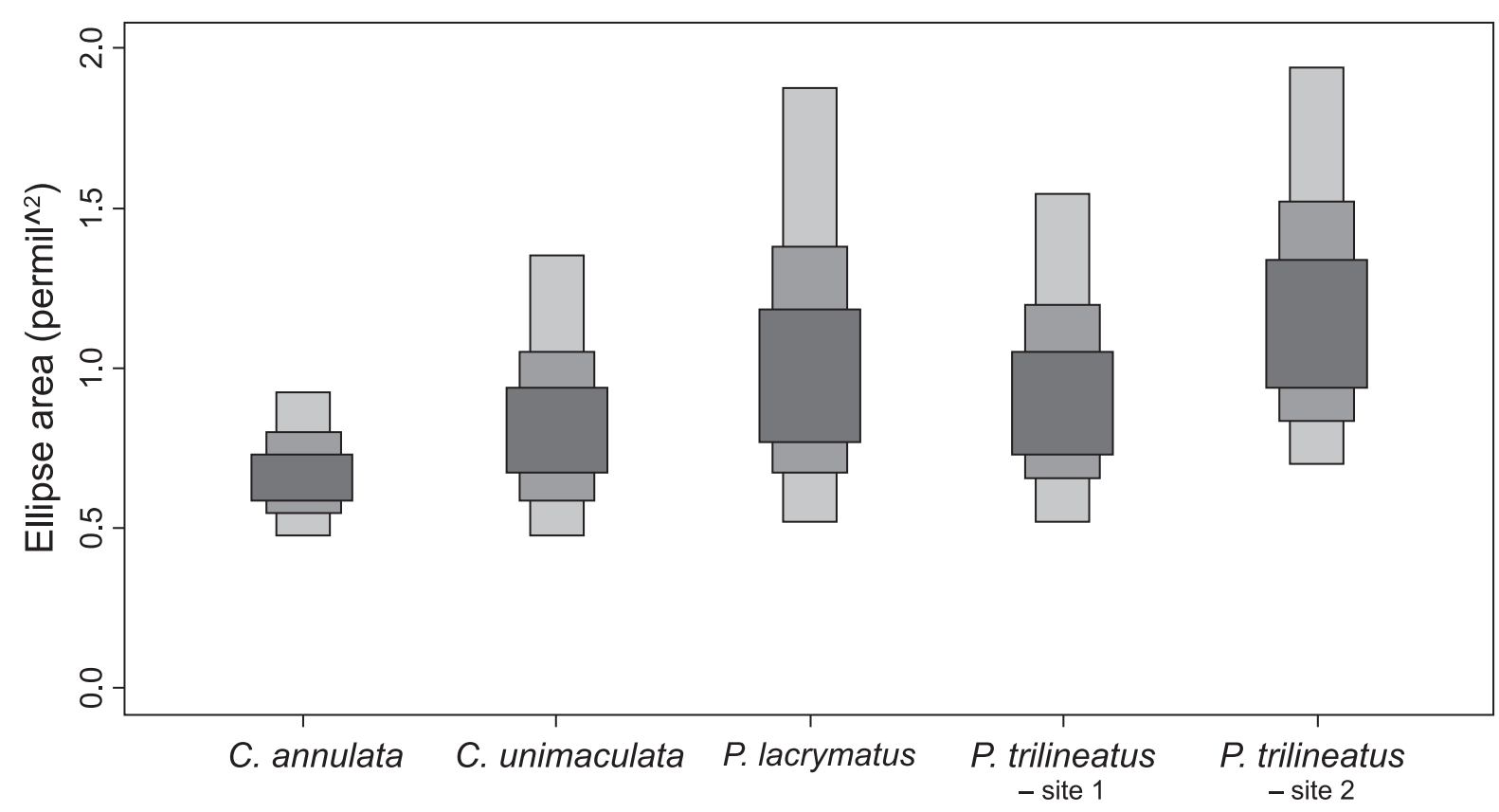

Fig. 4. - (a) Isotopic niches of Chrysiptera annulata, Chrysiptera unimaculata, Plectroglyphidodon lacrymatus and Pomacentrus trilineatus groups 1 and 2. Solid lines represent the bivariate standard ellipses associated to each group. (b) Boxplots of model-estimated bivariate standard ellipse area $\left(\mathrm{SEA}_{\mathrm{b}}\right)$. Dark, median and light grey boxes are respectively the $50 \%, 75 \%$ and $95 \%$ credibility intervals of the probability of density function distributions of the model solutions, and black dots are the modes of these distributions. 
focus on the assimilated part of the diet rather than the ingested one. The animal fraction could be more easily digested than algae and therefore could be rapidly degraded (KRAMER et al., 2013), contributing to the undetermined part of the stomach content (between 0 and 33\% of examined stomach contents). Thirdly, these undetermined items could be processed animal tissues but also detritus of animal origin (e.g. faeces) or mucus produced by corals embedded with organic debris (WILSON et al., 2003). Such material is known to compose sometimes a large part of the diet in coral reef fishes (WILSON et al., 2003). Here, these sources were impossible to take into account in our SIAR modelling, but DROMARD et al. (2013) reported contributions of about $30 \%$ of detritus in the diet of Stegastes planifrons and Stegastes adustus.

The diet of our species may be qualified as omnivorous with an important contribution of algal material. Such mix between animal and vegetal food sources is not uncommon in damselfishes (FRÉDÉRICH et al., 2009). In farming species such as Stegastes nigricans, HATA \& UMEZAWA (2011) observed a higher abundance of animal prey inside damselfish territory than outside, suggesting that these animals were also gardened and contributed significantly to $S$. nigricans diet. Other herbivorous fishes such as Scaridae also massively ingest the animals (mainly crustaceans) associated with turf algae (KRAMER et al., 2013). This supplementary food may provide adequate nutritional balance to individuals, with algae providing energy and animals supplying proteins (RAUBENHEIMER et al., 2005). The animal contribution to the diet of $C$. annulata decreases during growth and thus, the balance of animal and vegetal food sources varies across its ontogeny. Such ontogenetic diet variation has also been highlighted in other damselfish species (FRÉDÉRICH et al., 2010).

We also questioned if consumption of seagrass could represent an unexpected specialization of the footballer damselfish. Seagrasses in stomach contents were infrequent and represented only small amounts of material, suggesting "accidental" ingestion. Seagrasses were not a target food source for $C$. annulata, as stomachs of specialized seagrass grazers are generally full of seagrass pieces (HAVELANGE et al., 1997; GULLSTRÖM et al., 2011). Therefore, C. annulata did not use seagrasses as a food source but used meadows mainly as habitat. More importantly than seagrasses, the presence of small coral or rock boulders is determinant for the habitat of C. annulata, allowing the delimitation of small territories for it to defend. This fits the habitat description given by FISHELSON (1998) and the one observed in Mayotte (WICKEL et al., 2014) and Tanzania (GARPE \& ÖHMAN, 2003). It might also explain why $C$. annulata may be found elsewhere on the reef flat than in seagrass meadows. In summary, inhabiting seagrass meadow is not linked to a trophic specialisation of this territorial species but is more likely a habitat divergence compared to other territorial herbivorous damselfishes.

Few genera of damselfish are territorial and practice gardening (HATA \& KATO, 2002; CECCARELli et al., 2005; JONES et al., 2006) but this peculiar farming behaviour evolved several times during the evolutionary history of Pomacentridae (FRÉDÉRICH et al., 2013). Considering its territoriality, it is legitimate to examine if $C$. annulata may be considered as a gardener. In Stegastes spp., this gardening may ultimately lead to a Polysiphonia sp. monoculture (HATA \& KATO, 2004). Although we did not detail the algal species present on each territory, it is evident that it was not a monoculture as in some Stegates spp. However, the fact that each $C$. annulata conserved large algae without consuming it on each territory could be evidence of another type of gardening behaviour where macroalgae are conserved to allow gardening of their epiphytes and where algal community diversity, abundance and successional pattern are significantly affected by the fish (CECCARELLI et al., 2005). In this intermediary case, gardening does not necessarily result in a monoculture as in Stegastes nigricans (HATA \& KATO, 2002).

Our second objective was to compare the isotopic niches of four damselfishes displaying 
an important contribution from algae in their diet. There was little overlap among the isotopic niches of the four studied species, except between the two Chrysiptera species. The weak overlap among species could indicate that they differed in terms of trophic resource use, although algae constitute a large part of their food (FRÉDÉRICH et al., 2009). Differences in these isotopic niches may be related to trophic differences (i.e. different algal species, different proportion of animals in the diet) but also to trophic behaviour (i.e. farmers vs. foragers) and habitats (coral boulders, seagrass meadows, "vasques"). Indeed, isotopic niche variability is also determined by isotopic variability of sources and this one could be related to spatial variability (FLAHERTY \& BEN-DAVID, 2010). This was documented in the present study by the two populations of $P$. trilineatus differing significantly in their isotopic niches, probably partly because the isotopic composition of their food sources differs spatially. Nevertheless, we cannot reject the possibility that the two populations of $P$. trilineatus also differed in their trophic exploitation. In summary, isotopic niche must be seen as an integration of two axes of ecological niche: the trophic and the habitat axis (NEWSOME et al., 2007; FLAHERTY \& BENDAVID, 2010).

Despite very different habitats, the isotopic niches of the two Chrysiptera species overlapped significantly, showing they shared more food resources with each other than with $P$. trilineatus and P. lacrymatus. The two Chrysiptera species have a similar behaviour (i.e. defence of a small territory with algal cover) and, therefore, habitat difference in the Toliara great reef (seagrass meadow vs. coral rubbles) between these two species could be essential to mitigate interspecific competition. Such potential competition among species is also observed for gardeners of Stegastes genus (DROMARD et al., 2013). For the footballer demoiselle being one of the smallest damselfish in the area, inhabiting seagrass meadows could be a way to escape competition with other territorial damselfishes.

\section{CONCLUSIONS}

Chrysiptera annulata is an omnivorous species, mostly relying on algal material but complementing its diet with zooplankton and small zoobenthic organisms. Seagrass does not contribute significantly to its diet. Nevertheless, inhabiting seagrass meadow of the reefflat may be a way to reduce competition with other territorial herbivorous damselfishes that display similar trophic strategies. Our study revealed ecological variations among territorial damselfishes and efforts to study their role in this ecosystem must be encouraged.

\section{ACKNOWLEDGEMENTS}

Authors wish to thank the staff of the Institut Halieutique et des Sciences Marines (IHSM) of Toliara and, particularly Prof. Richard Rasolofonirina and Prof. Thierry Lavitra (Director) for their welcome and their logistical help. Prof. Igor Eeckhaut is also acknowledged for giving us the opportunity to use BIOMAR facilities. We also warmly thank our Vezo crew captain Noëlson for help during field sampling. G.L and B.F. are respectively Research Associate and Postdoctoral Researcher at the Belgian National Fund for Scientific Research (FRSFNRS). This study was supported by the Belgian National Fund for Scientific Research (F.R.S.FNRS) [grant numbers.F.R.F.C. 2.4.535.10.F and P.D.R. T.0056.13]. This publication is the MARE publication number 314

\section{REFERENCES}

AlLEN GR \& RANDALL JE (1980). A review of the damselfishes (Teleostei: Pomacentridae) of the Red Sea. Israel Journal of Zoology 29(1-3): 1-98.

ANDRÉFouËt S, Guillaume MMM, Delval A, RASOAMANENDRIKA FMA, BLANCHOT J \& BRUGGEMANN JH (2013). Fifty years of changes in reef flat habitats of the Grand Récif of Toliara (SW Madagascar) and the impact of gleaning. Coral Reefs 32(3): 757-768.

BELlWOOd DR, GOATLEY CHR, BRANDL SJ \& Bellwood O (2014). Fifty million years 
of herbivory on coral reefs: Fossils, fish and functional innovations. Proceedings of the Royal Society B: Biological Sciences 281(1781).

Caut S, Angulo E, Courchamp F \& Figuerola J (2010). Trophic experiments to estimate isotope discrimination factors. Journal of Applied Ecology 47(4): 948-954.

CEBRIAN J (2002). Variability and control of carbon consumption, export, and accumulation in marine communities. Limnology and Oceanography 47(1): 11-22.

Ceccarelli DM, Jones GP \& McCoOK LJ (2005). Effects of territorial damselfish on an algaldominated coastal coral reef. Coral Reefs 24(4): 606-620.

Ceccarelli DM, Jones GP \& McCook LJ (2011). Interactions between herbivorous fish guilds and their influence on algal succession on a coastal coral reef. Journal of Experimental Marine Biology and Ecology 399(1): 60-67.

ChoAt JH, RobBins WD \& Clements KD (2004). The trophic status of herbivorous fishes on coral reefs: II Food processing modes and trophodynamics. Marine Biology 145(3): 445-454.

COPLEN, T., B, (2011). Guidelines and recommended terms for expression of stable-isotope-ratio and gas-ratio measurements results. Rapid Communications in Mass Spectrometry 25: 2538-2560.

DROMARD CR, BOUCHON-NAVARO Y, CORDONNIER S, Fontaine MF, Verlaque M, HarmelinVIVIEN M \& BOUCHON C (2013). Resource use of two damselfishes, Stegastes planifrons and Stegastes adustus, on Guadeloupean reefs (Lesser Antilles): Inference from stomach content and stable isotope analysis. Journal of Experimental Marine Biology and Ecology 440: 116-125.

DROMARD CR, BOUCHON-NAVARO Y, HARMELINVIVIEN M \& BOUCHON C (2015). Diversity of trophic niches among herbivorous fishes on a Caribbean reef (Guadeloupe, Lesser Antilles), evidenced by stable isotope and stomach content analyses. Journal of Sea Research 95: 124-131.

FisHELSON L (1998). Behaviour, socio-ecology and sexuality in damselfishes (Pomacentridae). Italian Journal of Zoology 65(SUPPL): 387-398.

FLAHERTY EA \& BEN-DAVID M (2010). Overlap and partitioning of the ecological and isotopic niches. Oikos 119(9): 1409-1416.

FOX RJ \& BELLWOOD DR (2013). Niche partitioning of feeding microhabitats produces a unique function for herbivorous rabbitfishes (Perciformes, Siganidae) on coral reefs. Coral Reefs 32(1): 13-23.

FrÉDÉRICH B, FABRI G, LEPOINT G, VANDEWALLE P \& PARMENTIER E(2009). Trophic niches of thirteen damselfishes (Pomacentridae) at the Grand Récif of Toliara, Madagascar. Ichthyological Research 56(1): 10-17.

FRÉDÉRICH B, LEHANSE O, VANDEWALle $\mathrm{P}$ \& LEPOINT G (2010). Trophic Niche Width, Shift, and Specialization of Dascyllus aruanus in Toliara Lagoon, Madagascar. Copeia (2): 218-226.

FrédÉrich B, SORENSON L, SANTINI F, SLATER GJ \& ALFARO ME (2013). Iterative ecological radiation and convergence during the evolutionary history of damselfishes (Pomacentridae). American Naturalist 181(1): 94-113.

GARPE KC \& ÖHMAN MC (2003). Coral and fish distribution patterns in Mafia Island Marine Park, Tanzania: Fish-habitat interactions. Hydrobiologia 498: 191-211.

GILLIBRAND CJ, HARRIS AR \& MARA E (2007). Inventory and spatial assemblage study of reef fish in the area of Andavadoaka, South-West Madagascar (Western Indian Ocean). Western Indian Ocean Journal of Marine Science 6(2): 183-197.

GullstrÖM M, BerKSTRÖM C, ÖHMAN MC, BODIN M \& DAHLBERG M (2011). Scale-dependent patterns of variability of a grazing parrotfish (Leptoscarus vaigiensis) in a tropical seagrassdominated seascape. Marine Biology 158(7): 1483-1495.

HARMELIN-VIVIEN M (1979). Ichtyofaune des récifs coralliens de Tuléar (Madagascar): écologie et relations trophiques $\mathrm{PhD}$, University of AixMarseille II.

Harris A, Manahira G, Sheppard A, Gough C \& SHEPPARD C (2010). Demise of Madagascar's once great barrier reef-change in coral reef condition over 40 years Atoll Research Bulletin (574): 1-16.

Hata H \& Kato M (2002). Weeding by the herbivorous damselfish Stegastes nigricans in nearly monocultural algae farms. Marine Ecology Progress Series 237: 227-231.

HATA H \& KaTo M (2004) Monoculture and mixedspecies algal farms on a coral reef are maintained through intensive and extensive management by damselfishes. Journal of Experimental Marine Biology and Ecology 313:285-296. 
HATA H \& UMEZAWA Y (2011). Food habits of the farmer damselfish Stegastes nigricans inferred by stomach content, stable isotope, and fatty acid composition analyses. Ecological Research 26(4): 809-818.

Havelange S, Lepoint G, Dauby P \& BOUQUEGNEAU JM (1997). Feeding of the sparid fish Sarpa salpa in a seagrass ecosystem: Diet and carbon flux. Marine Ecology-Pubblicazioni Della Stazione Zoologica Di Napoli I 18(4): 289-297.

HeCK KL \& VALENTINE JF (2006). Plant-herbivore interactions in seagrass meadows. Journal of Experimental Marine Biology and Ecology 330(1): 420-436.

HYSLOP, E. J. 1980. Stomach contents analysis-a review of methods and their application. Journal of Fish Biology 17:411-429.

JACKSON AL, INGER R, PARNELL AC \& BEARHOP S (2011). Comparing isotopic niche widths among and within communities: SIBER - Stable Isotope Bayesian Ellipses in R. Journal of Animal Ecology 80(3): 595-602.

Jones GP, SANTANA L, MCCOOK LJ \& MCCORMICK MI (2006). Resource use and impact of three herbivorous damselfishes on coral reef communities. Marine Ecology Progress Series 328: 215-224.

KHALAF MA(2004). Fish fauna of the Jordanian Coast, Gulf of Aqaba, Red Sea. Journal of King Abdulaziz University: Marine Sciences 15(1): 23-50.

KLUMPP DW, SALITA-ESPINOSA JT \& FORTES MD (1993). Feeding ecology and trophic role of sea urchins in a tropical seagrass community. Aquatic Botany 45(2-3): 205-229.

KRAMER MJ, BELLWOOD O \& BELLWOOD DR (2013). The trophic importance of algal turfs for coral reef fishes: The crustacean link. Coral Reefs 32(2): 575-583.

Layman CA, ARAujo MS, BouceK R, HAMMERSCHLAG-PEYER CM, HARRISON E, JUd ZR, Matich P, Rosenblatt AE, Vaudo JJ, YeAger LA, Post DM \& BEARHOP S (2012). Applying stable isotopes to examine foodweb structure: An overview of analytical tools. Biological Reviews 87(3): 545-562.

LAYMAN CA, ARrington DA, MONTAÑA CG \& PosT DM (2007). Can stable isotope ratios provide for commu nity-wide measures of trophic structure? Ecology 88(1): 42-48.
Mill AC, Pinnegar J K \& Polunin NVC (2007). Explaining isotope trophic-step fractionation: Why herbivorous fish are different. Functional Ecology 21(6): 1137-1145.

NAKAMURA Y, HORINOUCHI M, NAKAI T \& SANO M (2003). Food habits of fishes in a seagrass bed on a fringing coral reef at Iriomote Island, southern Japan. Ichthyological Research 50(1): 15-22.

Newsome SD, Del Rio CM, BEARHop S \& PhILlipS DL (2007). A niche for isotopic ecology. Frontiers in Ecology and the Environment 5(8): 429-436.

PARNELl AC, INGER R, BEARHOP S \& JACKSON AL (2010). Source Partitioning Using Stable Isotopes: Coping with Too Much Variation. Plos One 5(3).

PICHON M (1978). Recherches sur les peuplements à dominance d'anthozoaires dans les récifs coralliens de Tulear. Atoll Research Bulletin 222: 490.

PLASS-JOHNSON JG, MCQUAID CD \& HILL JM (2013). Stable isotope analysis indicates a lack of inter- and intra-specific dietary redundancy among ecologically important coral reef fishes. Coral Reefs 32(2): 429-440.

Raubenheimer D, ZemKe-White WL, Phillips R J \& CLEMENTS KD (2005). Algal macronutrients and food selection by the omnivorous marine fish Girella tricuspidata. Ecology 86(10): 2601-2610.

VONK JA, Christianen MJA \& STAPEL J (2008). Redefining the trophic importance of seagrasses for fauna in tropical Indo-Pacific meadows. Estuarine Coastal and Shelf Science 79(4): 653-660.

Wickel J, Jamon A, Pinault M, DuRVille P \& Chabanet P (2014). Composition et structure des peuplements ichtyologiques marins de l'île de Mayotte (sud-oueast de l'océan indien). Cybium 38(3): 179-203.

WILSON S \& BellwoOD DR (1997). Cryptic dietary components of territorial damselfishes (Pomacentridae, Labroidei). Marine Ecology Progress Series 153(1-3): 299-310.

WILSON SK, BELLWOOD DR, CHOAT JH \& FURNAS MJ (2003). Detritus in the epilithic algal matrix and its use by coral reef fishes. Oceanography and Marine Biology: an annual review 41: 279-309.

Received: June 19th, 2015

Accepted: November 23rd, 2015

Branch editor: Steven Degraer 